\title{
Effect of corporal punishment on Sudanese pupils from parent's perspectives: part I
}

\begin{abstract}
Despite the fact that corporal punishment (cp) in schools and homes proved to be of serious consequences and of no benefit, it is still an acceptable tool of disciplining children over the world notably Sudan against national acts and international convention. The importance of this research is to serve the field of child protection with background information needed for strategic planning for the prevention and promotion of positive discipline. The aim was to Study the impact of corporal punishment on pupil's academic performance and behaviors form parent's perspective. Through comparative analytical study included 200 parents from two schools. Where School (A) using corporal punishment and school (B) declaring not using corporal punishment. The study was conducted in the period from first of June to $30^{\text {th }}$ of July 2013 using structured questionnaires that assessing socio demographic data, use of corporal punishment, believes behavior and academic consequences. Variables were completed and analyzed using parametric and non-parametric test within SPSS 16. The majority of parents were using $\mathrm{cp}$ to discipline their children at homes $(83.4 \%)$. Parental believes about $\mathrm{cp}$ as right and effective tool of child discipline; increase home/school CP and decrease child number of friends. Mother Low education was significantly associated with the use of CP ( $p$ value 0.02 ). Most of the parents found $\mathrm{CP}$ of no benefits in the long run. The use of $\mathrm{CP}$ at home acts as moderator with school $\mathrm{CP}$ that made the child dislike school and significantly increases children absence from school. Low parent's education, low income, parent's beliefs about CP and the presence of domestic violence were proved as predictors of use of $\mathrm{CP}$ at homes. Negative child characteristics and recurrent school requisition for Parents were significantly related to school (A), both p values $(0.01)$. Positive child characteristics significantly related to school (B). Although parents claimed that they rarely used CP in disciplining their children this rare use proved of negative consequences and of no benefits in long term and moral internalization. Reducing use of corporal punishment is found to be significantly associated to good behaviors and academic success. The research was replicating other international studies except increase rates of $\mathrm{CP}$ in children from 6-14years, the use of $\mathrm{CP}$ by the parent regardless of their age group. Using cp in School or at home decrease sense of safety and put the child at risk of bullying or violence.
\end{abstract}

Keywords: corporal punishment, academic performance, behavior
Volume 4 Issue I - 2016

\author{
Nahid M Elhassan \\ Hamad Medical Corporation-Psychiatry Department, University \\ of Medical Science and Technology, Sudan
}

\begin{abstract}
Correspondence: Nahid Mohammed Elhassan Ali, Assistant professor, University of Medical Science and Technology, Hamad Medical Corporation-Psychiatry Department, P.O Box 3050, Sudan,Tel +97430384007, Email nhfadul@gmail.com
\end{abstract}

Received:November 09, 2015 | Published: February 05, 2016

\section{Introduction}

Corporal punishment is defined as "the use of physical force with the intention of causing a child to experience pain, but not injury, for the purpose of correction or control of the child's behavior. Examples of frequent types of CP include slapping a child's hand or buttocks and squeezing a child's arm or others. ${ }^{1}$ Most of parents and teachers think that corporal punishment is the best way to motivate children in order to improve their behaviors and academic performance. Teachers and parents are not aware of the negative consequences of corporal punishment that proved by research and studies.

For the last few years, Ministry of Education-Khartoum State in collaboration with Child Rights Institute, started to work on ending corporal punishment in schools and promoting positive discipline. In 2010, Minister of Education in Khartoum State, issued article 10 that prohibited corporal punishment in primary schools in Khartoum State. In spite of this, some teachers outside and inside Ministry of Education still value corporal punishment as a tool of disciplining children in schools. Regardless, the dramatic increase in numbers of deaths and severe injuries due to corporal punishment in Sudanese schools. $^{2}$

The World Report on Violence against Children (2006) reveals the magnitude and significant impact of violence on children, noting that violence "occurs in every country in the world in a variety of forms and settings and is often deeply rooted in cultural, economic, and social practices." The Report has further established that while some violence are unexpected and isolated, most violent acts are carried out by the people children know and trust such as their parents, relatives, schoolmates, teachers or employers.

While the field of ending corporal punishment generates several researches, debates and studies around the world, in Sudan, the field of research in corporal punishment in schools and homes is still slightly touched. Sudan is a diverse country where corporal punishment is part of its cultural believes notably Muslim societies. Sudanese teachers are working in poor environment, where few teachers sometimeslike in Darfur-looking after hundreds of students in crowded classes. Teachers are underpaid, poorly trained and using old, primitive educational tools and methods. 


\section{State of education in Sudan}

The final report prepared by the Federal Ministry of Education in 2008, based on survey in basic education in Sudan revealed that; education system is composed of two main education levels which are; Basic Education and Secondary Education. Basic education is divided into two sub-successive education levels; Pre-education level (Khalwa and kindergartens) in which the education begins at age 4 and ends at 5 . And Basic education level begins at age 6 and ends at age 13. Then children enter Secondary Education level that composed of two types; Academic education and Technical education (Commercial education, Industrial education, Home Science and Agriculture). Both academic and technical education is three-year program. The Sudan growth enrolment for pre-school education is estimated at $23 \%$. The $2006 / 2007$ education statistics show that of the 333,856 pupils (148,055 females, 185,801 males) who sat to the Basic school certificate exams in the 15 Northern States, 237,730 (71.2\%) succeeded (among them 106,647 or $72 \%$ girls and 131,083 or $70.5 \%$ boys). Expenditure on education as a percentage of public expenditure was reported to be $2.9 \%$. Most communities have been playing an important role in providing different types of support for schools. It is believed that educational councils provide assistance to cover the daily running costs of the schools. International organizations and other regional and NGOs are also providing significant assistance (including school feeding and other essential services). The total number of teachers in general education reached 227,166 in 2007 of which 28185 are in pre-school. For basic education the total number of teachers is 145,999; (91,777 females, 54,222 males). The average pupils-teacher ratio in basic education is $1: 35$, lower than the 1:40 standard ratio for many developing countries while the average class size was 45 pupils /class. Although overall the ratio seems low to the advantage of Sudanese children, significant regional variations exist especially in Darfur States. Whereas the class size could exceed more than 100 pupils; this is especially in urban areas while in rural areas the average number of class size is less than 25 per class. The same can be argued about pupil's teacher. The percentage of trained teachers in basic education was estimated to be $66.3 \%$. The ratio of pupils to trained teacher was $1: 44$ in 2006/2007. Teachers training courses in educational sciences and teaching methods varied between short courses, up to two weeks, to long courses lasting for two to six months. $^{3}$

\section{Case presentation}

Cross-sectional comparative analytical Study was conducted in two governmental basic schools for boys, at (Karari) locality, in Khartoum state. Both schools were sharing the same socio-cultural environment, living in the same area and attended by different ethnic groups and almost the same level of economic situation. This area was selected after several researches and different visits to different schools; where; only one governmental school declared avoidance of corporal punishment and promotion of alternative discipline.

For the purpose of this research the school that using corporal punishment was labeled (A). And the school not using corporal punishment was labeled (B). The study was carried out in the period from the beginning of July 2013 to the end of August 2013.

The target groups were:

i. Teachers in both schools regardless of their gender, age or experiences who had spent at least one year before the research time.
They were 16, 26 in school (A),(B) respectively.

ii. Parents of student attending the selected school at least one year before the research time; and accepted to participate in the meeting, filled the questionnaires or responded to - by hand- questionnaires at home. ((Sample of 100 from each school).

iii. Student from second class primary school to the eighth class in both schools (sample of 100 from each school).

In order to capture the diversity of schooling conditions and experiences, a purposive sample from two government schools was used. In this article we will be analyzing Parents believes and attitudes towards $\mathrm{cp}$.

\section{For parents}

Research included any Parents of student attending the selected school at least one year before the research time. And accepted to attend the meeting and filling the questionnaires or responded to questionnaires at home. Invitation was send to parent to attend a meeting were questionnaires were filled from 157 person, who responded to invitation and accepted to fill the questionnaire as planned in school (A), (the school that using corporal punishment).

Questionnaires were send with open letter, that explain the purpose of research randomly to 200 families in School (B), (the school that not using corporal punishment) and 187 person responded. The first received 100 samples from any school were analyzed.

Questionnaires were tested through pilot study. And verbal informed consent was obtained from the students and their families. The ethical clearance was granted from the two schools and Ministry of Education, Training Department.

\section{Data analysis}

Statistical Package for Social Sciences (SPSS for Windows version 16.0) was used for data analysis. Frequencies cross tabs, Chi-square test, linear regression and multiple logistic regression analysis tests were applied.

\section{Results}

Parents were relatively young and educated. (35.5\%) of fathers were older than 45years, (46.5\%) of mothers between (35-45) years. Fathers $(69.5 \%)$ and mother $(66.5 \%)$ were educated to higher secondary school or university level. Most of the families (54\%) were living with 6-10 members in the same house. And the majority of families $(71.5 \%)$ were living with a monthly income of about 1000 SDG or less $(=$ or $<150 \$$ at the time of research). The majority of parents think that their children's health $(78 \%)$ and intelligence $(64.6 \%)$ were almost more than average.

\section{Acknowledgements}

None.

\section{Declaration of interest}

This research was carried out using a kind grant from Child Rights Institute -Sudan.

\section{Conflict of interest}

The author declares no conflict of interest. 


\section{References}

1. Straus MA, Sugarman DB, Giles-Sims J. Spanking by parents and subsequentantisocial behavior of children (article). Arch Pediatr Adolesc Med. 1977;151(8):761-767.

2. Nahed Mohammed Hassan. Guide educational alternatives to punishment Alibdna. Mahd Rights of the Child. Khartoum; 2011. p. 119-121.

3. The Republic of the Sudan. Federal Ministry of General Education. Directorate General of Educational Planning. Baseline survey on basic education in the Northern States of Sudan. In Partnership with the Ministry of International Cooperation, European Commission (EC), USA: United Nations Children's Fund (UNICEF) and World Food Programme (WFP); 2008. 